\title{
Potential Mixture of POFA and SCBA as Cement Replacement in Concrete - A Review
}

\author{
Noorwirdawati Ali ${ }^{1, *}$, Mohd Hazeeq Adhahuddinsa Mohd Sobri ${ }^{2}$, Josef Hadipramana $^{1}$, \\ Abdul Aziz Abdul Samad ${ }^{1}$, and Noridah Mohamad ${ }^{1}$ \\ ${ }^{1}$ Jamilus Research Center, Universiti Tun Hussein Onn Malaysia, 86400 Parit Raja, Johor, Malaysia \\ ${ }^{2}$ Faculty of Civil and Environmental Engineering, Universiti Tun Hussein Onn Malaysia, 86400 Parit \\ Raja, Johor, Malaysia
}

\begin{abstract}
Concrete is an important material used in all kind of building construction and ordinary Portland cement (OPC) is one of an important element in the production of concrete. However, the production of cement causes a problem because of high $\mathrm{CO}_{2}$ emission to atmosphere. The manufacture of 1 tonnes of cement would produce approximately released 1 tonnes of $\mathrm{CO}_{2}$. So, the need to search another material that can replace a cement with same properties and environmental friendly are crucial. The suitable material to replace cement has to be a pozzolanic materials. This is because pozzolanic materials has cementitious properties and high silica content. Palm oil fuel ash (POFA) and sugarcane bagasse ash (SCBA) are the material that suitable to replace cement because of high silica content. The use of POFA and SCBA in concrete has been studied by many researcher and it has been proved to improve the mechanical strength of the concrete either in normal concrete, high strength concrete or lightweight concrete. This paper would discuss the overview of the previous study on the cement replacement by POFA and SCBA and the potential of the both materials to be mix together to improve its properties. The chemical element which will be the focus point is $\mathrm{SiO}_{4}, \mathrm{MgO}, \mathrm{CaO}$ and $\mathrm{SO}_{3}$, while the physical and mechanical properties such as workability, specific gravity, compressive strength and tensile strength will also be reviewed.
\end{abstract}

\section{Introduction}

Nowadays, the population of the world is concern about the cost of building materials that keep increasing from day to day. With the increase in demand, the building materials are not enough for the provision of adequate housing for people in the world and cause the price of the materials keep increasing $[1,2]$. Besides that, the use of cement in construction are the most worrying environment concerns because it would release carbon dioxide $\left(\mathrm{CO}_{2}\right)$ gas to atmosphere. 5-7\% of world $\mathrm{CO}_{2}$ emissions are caused by this industry and it expected to increase because of an increasing demand of cement [3]. To prevent the problem become worst, many campaign and investigation had been done to search another

\footnotetext{
*Corresponding author: wirda@uthm.edu.my
} 
material as alternative to reduce the cement usage in construction. Many researchers are interested to use an agricultural and industrial waste as a potential cement materials (CRM) due to amount of waste that keep generated through years $[4,5]$. These waste did not produce new $\mathrm{CO}_{2}$ to atmosphere where $\mathrm{CO}_{2}$ is only cycled in the atmosphere. As such, it can be stated that the production of energy from biomass is a renewable energy. Today, 9$14 \%$ of energy sources of industrialized countries and 20-33\% from developing countries are contributed by biomass [6].

Malaysia is popular among the agricultural countries in the world with a major agriculture crops grown such as oil palm, sugarcane, coconut and rubber. From 32.90 million ha of total land of Malaysia, $14.9 \%$ of it is applied for agricultural activities while $61 \%$ of it are still being a natural forest [7]. As a popular vegetable oil for cooking and food processing, palm oil has produce a huge amount of waste throughout the year. Malaysia is one of the world's largest producer and exporter of palm oil in the world where palm oil plantation covers 4.98 Mha of the land area with about 417 palm oil mills throughout the country. These factors allow it to produce massive amount of palm oil by-product such as empty fruit bunch, oil palm shell and POFA. The amount of these products are increasing every year. It expected in 2020, the number of solid biomass would reach 100 million dry tonnes [7-9]. The other agriculture waste need to be concerned is sugarcane bagasse. Sugarcane bagasse is a fibrous waste that left after extraction and crushing processes [7]. For bagasse ash, it was a by-product that unused in sugar mill industries and can be used to replace a Portland cement due to its pozzolanic properties. Each year, around 410,000 to 620,000 tons of bagasse was produced and the trend are likely to increase every year. It is causes by the fact that the sugarcane is known as one of the agricultural crops and it was an important raw material in the production of ethanol. There are some utilization of bagasse ash such as backfill or fertilizers but the utilization is still minimum and poorly managed. Most of the bagasse ash is dumped in landfills and cause pollution and environmental problem [10].

Supplementary Cementing Materials (SCM) is the farming waste materials that had been utilized and POFA and SCBA are the example of SCM. These materials would achieve a high amount of silica after burning at a high temperature and enables it to show its pozzolanic reactivity. Pozzolanic properties is important for the later age strength development of the concrete [11]. In this study, POFA and SCBA will be mixed to stabilize the chemical content of both materials. Each material has an element that need to added and reduced. The silica content $\left(\mathrm{SiO}_{4}\right)$ of POFA and SCBA is quite similar, which is in range of $59.62 \%$ to $66.91 \%$ for POFA and $50.90 \%$ to $65.26 \%$ for SCBA, respectively. MgO content in POFA is quite high which is $3.00 \%$ to $4.52 \%$ and it range quite higher compared to OPC which is just around $1.20 \%$ to $4.80 \%$. For POFA, it contained high percentages of sulphur trioxide $\left(\mathrm{SO}_{3}\right)$ which is in range of $0.30 \%$ to $1.28 \%$ compared to $0.04 \%$ to $0.21 \% \mathrm{SO}_{3}$ for $\mathrm{SCBA}$ [12]. $\mathrm{SO}_{3}$ is important because it may cause expansion which compensates shrinkage. The mixture with higher $\mathrm{SO}_{3}$ content would results in lesser shrinkage [13].

\section{Cement}

\subsection{Physical properties}

From the finding of previous research, an ordinary Portland cement has a specific surface area of $0.325 \mathrm{~m}^{2} / \mathrm{g}$ with a density of $3.11 \mathrm{~g} / \mathrm{cm}^{3}$. The particle size distribution are in the range of 1.2 to $5.0 \mu \mathrm{m}$ [14]. The specific gravity of the cement mortar with OPC is 3.16 with a fineness and soundness value of $3.10 \mathrm{~m}^{2} / \mathrm{kg}$ and $1.61 \mathrm{~mm}$ [15]. It was also found that the cement mortars with OPC has a porosity of $12.21 \%$ and water absorption of $6.20 \%$ [16]. 


\subsection{Mechanical properties}

A cement paste has a compressive strength value of $41.5 \mathrm{MPa}$ with a modulus of rupture of $11 \mathrm{MPa}$. Other than that it has modulus of elasticity of $1270 \mathrm{MPa}$ and toughness value of $340 \mathrm{~J} / \mathrm{m}^{2}$. The value of bulk density of the cement paste is $1.85 \mathrm{~g} / \mathrm{cm}^{3}$ with water absorption and porosity value of $16 \%$ and $29 \%$ [17]. Results from previous research has recorded that the the compressive and flexural strength of cement is $47 \mathrm{MPa}$ and $9.23 \mathrm{MPa}$ after 28 days while the drying shrinkage of cement at 28 days is $0.076 \%$ [18].

\subsection{Chemical properties}

From the finding of previous research, OPC contained high lime content $(\mathrm{CaO})$ which is around $61.50 \%$ to $65.4 \%$ followed by silica $\left(\mathrm{SiO}_{4}\right)$ in range $20.40 \%$ to $21.98 \%$. It is followed by alumina $\left(\mathrm{Al}_{2} \mathrm{O}_{3}\right)$ with range $3.68 \%$ to $5.27 \%$. Iron $\left(\mathrm{Fe}_{2} \mathrm{O}_{3}\right)$ and magnesia $(\mathrm{MgO})$ with range content of $2.27 \%$ to $4.19 \%$ and $1.20 \%$ to $4.80 \%$ each [12].

\subsection{Cement hydration}

Cement hydration is a process when a cement is mixed with water and become a cement paste. It was a complex chemical reaction and these process cannot be reversed. This reaction is influenced by several factors, both internal and external factors. An examples of factors that influenced the hydration process is temperatures and the superplasticizer presence in the mixture. These factor are important because it plays an important role in hydration process and significantly influence the characteristics time. Porosity and pore size of the produced cement based materials also important for hydration process because it influences the final strength and durability of the concrete [19].

There are 5 stages during the hydration process. The stage is namely as initial reaction period, induction period, acceleration period, deceleration period and slow reaction period. The peaks process occur twice which is at initial reaction period and at the end of acceleration period and both of them known as first peak and second peak. The first peak is important for production of calcium sulfoaluminate hydrate (AFt) that formed from ion dissolution between $\mathrm{C}_{3} \mathrm{~A}$ and calcium sulphate. The second peak is producing $\mathrm{C}-\mathrm{S}-\mathrm{H}$ and calcium hydroxide $(\mathrm{CH})$ from the $\mathrm{C}_{3} \mathrm{~S}$ hydration that happen during the stage [20].

\section{Pozzolanic material}

Pozzolan materials is defined by Kanning et al. [21] as a materials that contain high amount of silica and alumina in it chemical structure. These materials may have a little or no portions of cement, so it need to be grinded into a fine size particle because it would form a compound with the cementitious properties when react with calcium hydroxide in a water at ordinary temperatures. In the end, the pozzolanic activity would arises cause by the reaction between amorphous silica and $\mathrm{Ca}(\mathrm{OH})_{2}$ which form a calcium silicate hydrate gel $(\mathrm{C}-\mathrm{S}-\mathrm{H})$ that important to improve the mechanical properties of concrete.

The first empire used a pozzolanic materials in construction are Roman Empire and it continuously used for ecology and technology purposes. It had been proved that it can produce a strong and durable materials when it mixed with lime and the performance is better compare to Portland cement [22]. In this study, pozzolan is the main element that would be used because POFA and SCBA is well-known as a pozzolanic materials which can be used as cement replacement and has been proved by many researchers. To activate the pozzolan in the concrete mixture, the hydration process of cement is needed to characterize the pozzolanic activity of the paste. Calcium hydroxide was form by the 
hydration process of almost $28 \mathrm{wt} \%$ of ordinary Portland cement. In the end, hydrated calcium silicates are formed from the reaction between calcium hydroxide in water and amorphous $\mathrm{SiO}_{2}$ in a pozzolanic materials [23].

The pozzolanic activity of the pozzolanic materials are affected by its burning process. The pozzolan is formed from the orthosilicic acid which come from the ground water and later it become an amorphous silica by polymerization in the plant cell. Reactive amorphous silica is formed when the agriculture waste is being burn or used as fuel [24].

\section{Properties of concrete with POFA}

\subsection{Physical properties}

POFA has a varying specific gravity, however its value never exceeded 3.0. The specific gravity of POFA would be increase after the grinding process because of a decrease of porosity. An increase of POFA replacement level would decrease the workability of concrete composites [25]. Drying shrinkage of POFA concrete has the same value as OPC concrete when $10 \%$ of OPC is replace by POFA. However, the shrinkage increased slightly at 28 days because of the increasing of unground POFA percentage as a cement replacement [25].

However, the water requirement for concrete with POFA is higher compared to normal concrete. So, the production of concrete with POFA will require more water [25]. The workability and density of the concrete also tends to decrease with the increased of POFA replacement $[26,27]$.

\subsection{Mechanical properties}

From the finding of Khankhaje et al. [25], the compressive strength of concrete decreased with the increased of percentage replacement of POFA and it depends on the finest of the POFA particles. However, for tensile strength, it shows an improvement where a specimen with $0.4 \mathrm{POFA} /$ cement ratio has a tensile value of approximately $3.52 \mathrm{MPa}$. This value is $9 \%$ higher compared to control mix and $16 \%$ higher than a specimen with 1.2 POFA/cement ratio. For modulus of elasticity (MOE), the specimen mixed with POFA either fine or coarse are in range of 25.0 to $28.0 \mathrm{GPa}$. The value are quite similar to OPC concrete which is $27.5 \mathrm{GPa}$ [25].

However, after POFA replaced a cement by $50 \%$, the compressive and tensile strength drop and recorded lower value than normal concrete [25]. Other than that, slow pozzolanic reactivity of POFA would decrease the early strength of concrete due to low $\mathrm{C}_{3} \mathrm{~S}$ content that only presence in cement [28].

\section{Properties of concrete with SCBA}

\subsection{Physical properties}

Previous research has proven that SCBA has a value of specific surface area which is three times higher compare to OPC because SCBA is finer. Therefore, it required more water in concrete production [29]. Since processed SCBA has lower specific gravity compared to OPC, the powder volume needed is higher and it lead to higher water requirement to reach the same workability as normal concrete. The rate of drying shrinkage also increases initially but then it start to slightly decrease [24]. When cement is replaced with SCBA, the 
volumetric weight of concrete will decreased cause by the low density of the ash [30]. The friction between cement and SCBA particles also increased cause by angularity, irregular shape and high porosity of SCBA [31].

\subsection{Mechanical properties}

When a $20 \%$ of cement is replaced with SCBA in concrete, the compressive strength of concrete shows an increase by $10 \%$ compared to normal concrete. However, the strength shows a reduction when the cement is replaced by $15-25 \%$ of SCBA [24]. For tensile strength, 20\% replacement of bagasse ash shows an increase of tensile strength up to 4.81 $\mathrm{MPa}$. However, at $25 \%$ to $30 \%$ replacement, the values decrease to $3 \mathrm{MPa}$ [12]. Other than that, an addition of sugarcane bagasse fiber are able to increase the modulus of elasticity of the epoxy and it also would improve if the bagasse is mix with glass fibre [32]. Replacement level, composition and fineness of SCBA and cement are the factor that influence the improvement of compressive strength and tensile strength of concrete [29].

\subsection{Chemical properties}

Similar as POFA as pozzolanic materials, SCBA also has high content of silica $\left(\mathrm{SiO}_{2}\right)$ which is in the range $59.90 \%$ to $84.1 \%$. Iron $\left(\mathrm{Fe}_{2} \mathrm{O}_{3}\right)$ and alumina $\left(\mathrm{Al}_{2} \mathrm{O}_{3}\right)$ content in SCBA are between $0.4 \%$ to $5.52 \%$ and $0.9 \%$ to $9.05 \%$, respectively. Other than that, the content of magnesia $(\mathrm{MgO})$ and lime $(\mathrm{CaO})$ are in the range of $1.10 \%$ to $2.85 \%$ and $2.5 \%$ to $10.5 \%$ [4, $12]$.

\section{Compatibility of the mixture of POFA and SCBA to replace cement}

A materials need to have a compatibility to be mixed to replace a cement either by chemical or mechanical properties. For POFA and SCBA, there are several elements in each material that can be improved. According to Aprianti [12], the silica content $\left(\mathrm{SiO}_{4}\right)$ of POFA and SCBA is higher compared to OPC, which in the range of $59.62 \%$ to $66.91 \%$ for POFA and $50.90 \%$ to $65.26 \%$ for SCBA. However, the finding of Embong et al. [4] stated that $\mathrm{SiO}_{4}$ content for SCBA can reach up to $84.1 \%$ if it was treated with acid treatment and burnt at suitable temperature. Aprianti [12] also stated that $\mathrm{MgO}$ content in POFA was quite high which is around $3.00 \%$ to $4.52 \%$ and it range higher compared to OPC which is just around $1.20 \%$ to $4.80 \%$. According to Aitcin [33], when the $\mathrm{MgO}$ content is too high, a detrimental expansive action can occur in hardened concrete. The late hydration of periclase, the crytalline form of $\mathrm{MgO}$ in Portland cement clinkers, in the form of brucite $\mathrm{Mg}(\mathrm{OH})_{2}$, results in volumetric expansion that can lead to a severe cracking of concrete. Therefore, $\mathrm{SCBA}$ is chosen to be mixed with POFA to stabilize the content of $\mathrm{MgO}$ in POFA because $\mathrm{MgO}$ content in SCBA is just around $1.10 \%$ to $2.85 \%$. The range of lime content $(\mathrm{CaO})$ in SCBA is $4.01 \%$ to $10.5 \%$ which is higher compared to POFA where it contain $\mathrm{CaO}$ in the range of $4.92 \%$ to $6.4 \%$ [12]. According to Kaewmanee et al. [13], lime is important to early setting and contribute to a higher compressive strength, especially in early ages of concrete. Aprianti [12] found that $\mathrm{OPC}$ also contained high $\mathrm{CaO}$ content in range of around $61.50 \%$ to $65.4 \%$.

For POFA, it contained high percentages of sulphur trioxide $\left(\mathrm{SO}_{3}\right)$ which is in the range of $0.30 \%$ to $1.28 \%$ compared to $0.04 \%$ to $0.21 \% \mathrm{SO}_{3}$ for SCBA. OPC itself contained a high value of $\mathrm{SO}_{3}$ which is in range of $2.19 \%$ to $2.95 \%$ compared to POFA and SCBA [12]. From the finding of Embong et al. [4], $\mathrm{SO}_{3}$ content in SCBA can reach $0.50 \%$ if it is 
treated with acid treatment and burnt at suitable temperature. According to Kaewmanee et al. [13], $\mathrm{SO}_{3}$ is important because it may causes expansion which compensates shrinkage. The mixture with higher $\mathrm{SO}_{3}$ content would results in less shrinkage. Therefore, POFA can help in increasing the content of $\mathrm{SO}_{3}$ when mix with SCBA in concrete. Table 1 shows range of chemical content of POFA and SCBA in percentage $[4,12]$.

Table 1. Range of chemical content of POFA and SCBA in percentage $[4,12]$

\begin{tabular}{|l|c|c|}
\hline \multicolumn{1}{|c|}{ Chemical Content } & POFA & SCBA \\
\hline Silica / Silicon dioxide $\left(\mathrm{SiO}_{2}\right)$ & $59.62 \%-66.91 \%$ & $59.90 \%-84.1 \%$ \\
\hline Iron / Ferric Oxide $\left(\mathrm{Fe}_{2} \mathrm{O}_{3}\right)$ & $1.9 \%-5.72 \%$ & $0.4 \%-5.52 \%$ \\
\hline Alumina / Aluminium Trioxide $\left(\mathrm{Al}_{2} \mathrm{O}_{3}\right)$ & $2.5 \%-6.44 \%$ & $0.9 \%-9.05 \%$ \\
\hline Lime content / Calcium Oxide $(\mathrm{CaO})$ & $4.92 \%-6.4 \%$ & $2.50 \%-10.5 \% \%$ \\
\hline Sulfuric Anhydride / Sulfur Trioxide $\left(\mathrm{SO}_{3}\right)$ & $0.30 \%-1.28 \%$ & $0.04 \%-0.50 \%$ \\
\hline Magnesia / Magnesium Oxide $(\mathrm{MgO})$ & $3.00 \%-4.52 \%$ & $1.10 \%-2.85 \%$ \\
\hline Potassium Oxide $\left(\mathrm{K}_{2} \mathrm{O}\right)$ & $4.97 \%-7.52 \%$ & $1.35 \%-2.50 \%$ \\
\hline Sodium Oxide $\left(\mathrm{Na}_{2} \mathrm{O}\right)$ & $0.19 \%-0.76 \%$ & $0.30 \%-0.92 \%$ \\
\hline LOI & $6.57 \%-10.02 \%$ & $0.2 \%-19.60 \%$ \\
\hline
\end{tabular}

\section{Conclusion}

In short, this paper summarized the properties of POFA and SCBA in normal concrete as cement replacement. From the previous research, POFA and SCBA have proven to improve the physical and mechanical properties of concrete. However, each materials has its deficiency when it mixed with concrete in term of their properties especially chemical properties. So, these materials has a potential to be mixed together to get an optimum mixture that would have quite similar or approaching the similar properties of OPC. Consequently, the production of sustainable and green concrete could be realized. From the result, it would lead to waste conservation and at the same time reduce the negative impact on the environment. This would ultimately lead to a more sustainable construction for the construction industry and the same time a cleaner environment for the society to live in.

This research was supported by Short Term Grant, Universiti Tun Hussein Onn Malaysia (Project Vote No: U340).

\section{References}

[1] D.A. Adesanya and A.A. Raheem, Development of corn cob ash blended cement, Construction and Building Materials, 23(1), 347-352 (2009)

[2] S.R. Abdullah, W.R. Wan Zainal Abidin and S. Shahidan, Strength of Concrete Containing Rubber Particle as Partial Cement Replacement, MATEC Web Conf., 47, 01009 (2016)

[3] K. Hung, U.J. Alengaram, M. Zamin and S. Poh, Feasibility study of high volume slag as cement replacement for sustainable structural lightweight oil palm shell concrete, J. of Cleaner Production, 91, 297-304 (2015) 
[4] R. Embong, N. Shafiq, A. Kusbiantoro and M.F. Nuruddin, Effectiveness of lowconcentration acid and solar drying as pre-treatment features for producing pozzolanic sugarcane bagasse ash, J. of Cleaner Production, 112, 953-962 (2016)

[5] S. Shahidan, I. Isham and N. Jamaluddin, A Review on waste minimization by adopting in self compacting concrete, MATEC Web Conf., 47, 1-7 (2016)

[6] A. Pereira, J.L. Akasaki, J.L.P. Melges, M.M. Tashima, L. Soriano, M.V. Borrachero, and J. Payá, Mechanical and durability properties of alkali-activated mortar based on sugarcane bagasse ash and blast furnace slag, Ceramics Int., 41(10), 1-13 (2015)

[7] K.Y. Foo, A vision on the opportunities, policies and coping strategies for the energy security and green energy development in Malaysia. Renewable and Sustainable Energy Reviews, 51, 1477-1498 (2015)

[8] M.F. Awalludin, O. Sulaiman, R. Hashim, and W.N.A.W. Nadhari, An overview of the oil palm industry in Malaysia and its waste utilization through thermochemical conversion, specifically via liquefaction. Renewable and Sustainable Energy Reviews, 50, 1469-1484 (2015)

[9] M.E. Rahman, A.L. Boon, A.S. Muntohar, M.N. Hashem Tanim, and V. Pakrashi, Performance of masonry blocks incorporating Palm Oil Fuel Ash. J. of Cleaner Production, 78, 195-201 (2014)

[10]A. Rerkpiboon, W. Tangchirapat, and C. Jaturapitakkul, Strength, chloride resistance, and expansion of concretes containing ground bagasse ash. Construction and Building Materials, 101, 983-989 (2015)

[11] K.H. Mo, U. Johnson Alengaram, M.Z. Jumaat, S.P. Yap, and S.C. Lee, Green concrete partially comprised of farming waste residues: A review. J. of Cleaner Production, 117, 122-138 (2016)

[12] S.E. Aprianti, A Huge Number of Artificial Waste Material can be Supplementary Cementitious Material (SCM) for Concrete Production - A review Part II. J. of Cleaner Production. Elsevier Ltd. 142, 4178-4194 (2016)

[13]K. Kaewmanee, P. Krammart, T. Sumranwanich, P. Choktaweekarn, and S. Tangtermsirikul, Effect of free lime content on properties of cement-fly ash mixtures. Construction and Building Materials, 38, 829-836 (2013)

[14] M. S. Kirgiz, Advancements in mechanical and physical properties for marble powdercement composites strengthened by nanostructured graphite particles. Mechanics of Materials, 92, 223-234 (2016)

[15]A. Bahurudeen, D. Kanraj, V. Gokul Dev and M. Santhanam, Performance evaluation of sugarcane bagasse ash blended cement in concrete. Cement and Concrete Composites, 59, 77-88 (2015)

[16]P. Lertwattanaruk and A. Suntijitto, Properties of natural fiber cement materials containing coconut coir and oil palm fibers for residential building applications. Construction and Building Materials, 94, 664-669 (2015)

[17] G.A.M. Brasileiro, J.A.R. Vieira, and L.S. Barreto, Use of coir pith particles in composites with Portland cement. J. of Environmental Management, 131, 228-238 (2013)

[18]K. Zheng, J. Zhou and M. Gbozee, Influences of phosphate tailings on hydration and properties of Portland cement. Construction and Building Materials, 98, 593-601 (2015)

[19]A. Pop and I. Ardelean, Monitoring the size evolution of capillary pores in cement paste during the early hydration via diffusion in internal gradients. Cement and Concrete Research, 77, 76-81 (2015)

[20]J. Han, K. Wang, J. Shi, and Y. Wang, Mechanism of triethanolamine on Portland cement hydration process and microstructure characteristics. Construction and Building Materials, 93, 457-462 (2015) 
[21] R.C. Kanning, K.F. Portella, M.O.G.P. Bragança, M.M. Bonato, J.C.M. Dos Santos, Banana leaves ashes as pozzolan for concrete and mortar of Portland cement. Construction and Building Materials, 54, 460-465 (2014)

[22]J.C.B. Moraes, J.L. Akasaki, J.L.P. Melges, J. Monzó, M.V. Borrachero, L. Soriano, M.M. Tashima, Assessment of sugar cane straw ash (SCSA) as pozzolanic material in blended Portland cement: Microstructural characterization of pastes and mechanical strength of mortars. Construction and Building Materials, 94, 670-677 (2015)

[23]P. Šiler, P. Bayer, T. Sehnal, I. Kolářová, T. Opravil, and F. Šoukal, Effects of hightemperature fly ash and fluidized bed combustion ash on the hydration of Portland cement. Construction and Building Materials, 78, 181-188 (2015)

[24]A. Bahurudeen and M. Santhanam, Cement \& Concrete Composites Influence of different processing methods on the pozzolanic performance of sugarcane bagasse ash. Cement and Concrete Composites, 56, 32-45 (2015)

[25]E. Khankhaje, M.W. Hussin, J. Mirza, M. Rafieizonooz, M.R. Salim, H.C. Siong and M.N.M. Warid, On blended cement and geopolymer concretes containing palm oil fuel ash. Materials and Design, 89, 385-398 (2016)

[26]A.S.M.A. Awal, and I.A. Shehu, Evaluation of heat of hydration of concrete containing high volume palm oil fuel ash. Fuel, 105, 728-731, (2013)

[27]N. Ranjbar, M. Mehrali, U.J. Alengaram, H.S.C. Metselaar and Jumaat, Compressive strength and microstructural analysis of fly ash/palm oil fuel ash based geopolymer mortar under elevated temperatures. Construction and Building Materials, 65, 114-121 (2014)

[28] M. Momeen Ul Islam, K.H. Mo, U.J. Alengaram and M.Z. Jumaat, Mechanical and fresh properties of sustainable oil palm shell lightweight concrete incorporating palm oil fuel ash, J. of Cleaner Production, 115, 307-314 (2015)

[29]K. Ganesan, K. Rajagopal, and K. Thangavel, Evaluation of bagasse ash as supplementary cementitious material, Cement and Concrete Composites, 29(6), 515524 (2007)

[30]J.C. Arenas-piedrahita, P. Montes-garcía, J.M. Mendoza-rangel and H.Z.L. Calvo, Mechanical and durability properties of mortars prepared with untreated sugarcane bagasse ash and untreated fly ash, Construction and Building Materials, 105, 69-81, (2016)

[31] G. Sua-iam and N. Makul, Use of increasing amounts of bagasse ash waste to produce self-compacting concrete by adding limestone powder waste, J. of Cleaner Production, 57, 308-319, (2013)

[32]D. Verma, P.C. Gope, M.K. Maheshwari and R.K. Sharma, Bagasse fiber compositesA review, J. of Materials and Environmental Science, 3(6), 1079-1092 (2012)

[33]P.C. Aitcin, Binders for Durable and Sustainable Concrete, Taylor \& Francis Group, Abingdon, Oxon, United Kingdom, (2008) 